\title{
Ensemble models on palaeoclimate to predict India's groundwater challenge
}

\section{Modelli ensamble del paleoclima per la previsione della disponibilità di acque sotterranee in India}

Partha Sarathi Datta

\begin{abstract}
Riassunto: In molte parti del mondo le crisi di disponibilità idriche sono spesso legate all'incremento del consumo di acqua e al suo grado di contaminazione, fenomeni dovuti sia alla rapidità di crescita della popolazione che allo sviluppo economico, ma comunemente attribuite ai cambiamenti climatici. Tuttavia nelle zone tropicali la limitata conoscenza dei fattori che controllano il clima, unita alla incertezza intrinseca dei modelli climatici, impediscono di valutare in modo esaustivo l'effettivo impatto del clima sulla disponibilità di risorsa idrica. In tale contesto, nella regione Nord Ovest dell'India è stato effettuato uno studio per ricostruire il paleoclima e la ricarica di lungo periodo, facendo uso di una rassegna di vari modelli ensamble sulla presenza di $\delta^{18} \mathrm{O}$ e $\delta \mathrm{D}$ nelle acque meteoriche e in quelle sotterranee, sull'età di isotopi ${ }^{3} \mathrm{H}^{-}$e ${ }^{14} \mathrm{C}^{-}$nelle acque sotterranee e dell'isotopo ${ }^{14} \mathrm{C}$ in sedimenti lacustri. $\mathrm{La}$ tendenza della temperatura media annua indica effetti sia di riscaldamento che di raffreddamento in diverse parti dell'India nel passato e nel periodo 1901-2010.
\end{abstract}

Né i GCMs (Global Climate Models) né le osservazioni re-

Parole chiave: Modello Ensamble, Clima, Acque sotterranee, Isotopi, Gestione della risorsa idrica

Keywords: Model Ensemble, Climate, Groundwater, Isotope, Management

Partha Sarathi DATTA 瑾"

Independent Consultant on Water and Environment

87, Kadambari Apartments, Sec-9, Plot-19

Rohini, Delhi - 110085, India

psdatta1950@gmail.com

Ricevuto: 13 marzo 2013 / Accettato: 28 agosto 2013

Pubblicato online: 30 settembre 2013

(C) Associazione Acque Sotterranee 2013 gistrate indicano alcun cambiamento/incremento significativo della temperatura e della piovosità durante l'ultimo secolo, né cambiamenti climatici durante gli ultimi 1200 anni. Nella maggior parte della regione Nord Ovest, la ricarica degli acquiferi profondi proviene dal passato clima di tipo umido, mentre negli acquiferi superficiali si evidenzia una limitata ricarica recente relativa alle ultime decadi. Per comprendere se la gestione delle risorse idrica sia maggiormente sensibile al cambiamento climatico occorre che siano colmate le varie lacune ancora presenti nella disciplina che studia tale fenomeno.

Abstract: In many parts of the world, freshwater crisis is largely due to increasing water consumption and pollution by rapidly growing population and aspirations for economic development, but, ascribed usually to the climate. However, limited understanding and knowledge gaps in the factors controlling climate and uncertainties in the climate models are unable to assess the probable impacts on water availability in tropical regions. In this context, review of ensemble models on $\delta^{18} \mathrm{O}$ and $\delta D$ in rainfall and groundwater, ${ }^{3} \mathrm{H}^{-}$and ${ }^{14} \mathrm{C}$ - ages of groundwater and ${ }^{14} \mathrm{C}$-age of lakes sediments helped to reconstruct palaeoclimate and long-term recharge in the North-west India; and predict future groundwater challenge. The annual mean temperature trend indicates both warming/cooling in different parts of India in the past and during 1901-2010. Neither the GCMs (Global Climate Models) nor the observational record indicates any significant change/increase in temperature and rainfall over the last century, and climate change during the last 1200 yrs BP. In much of the North-West region, deep groundwater renewal occurred from past humid climate, and shallow groundwater renewal from limited modern recharge over the past decades. To make water management to be more responsive to climate change, the gaps in the science of climate change need to be bridged. 


\section{Introduction}

In the recent decades, in many parts of India, the freshwater crisis at different times are largely due to non-climatic factors, such as, increased water consumption and pollution with rapid growth in population, urbanization, agricultural intensification, industrialization, and competition for economic aspirations (Datta et al, 2001; Datta, 2005, 2011), but, the crisis is ascribed usually to the climate. Spatial and temporal variations in storms, heavy rainfall, floods, droughts, etc. either mask or regulate or aggravate water shortage. The area irrigated by groundwater increased about six times since 1951. Inadequate supply of surface water has forced millions of pumping decisions to indiscriminately withdraw limited groundwater, most of which accumulated over years, centuries or millennia by renewal only during a part of each year. Some undeniable facts are that climate has two stable modes - hot and cold, and in the Indian region the current 'hot' state is stable for past 10,000 yrs; and during Neogene (23-6 $\mathrm{My}$, the climate in the SE Asia, humid tropics and subtropics was not substantially different, and the tropics and northern extra-tropics had distinctly different response by 100,000 year glacial-interglacial cycle, and $\sim 19,000-3,000$ years precessional cycles of monsoons (Chiang, 2009). While many current climate models predict strongly anomalous wetter Central Asia; well-validated proxy reconstructions indicate the opposite, particularly prior to late 20th century (Anchukaitis et al., 2010). Despite differences in the climate models, link of the East Asian and Indian monsoons in the region is reported (Cai et al. 2006). Due to uncertainty in prediction of the future rainfall and the land use, the general scenarios based on the GCMs and RCMs (Regional Climate Models) make it difficult to understand the impacts of climate change on groundwater.

The present knowledge status on the groundwater systems, and the climate, water demand and use have limitations to predict well the probable impacts and the mechanisms that govern water availability, at the level at which a management response is required. Therefore, it is matter of concern for the planners and decision makers how to overcome the uncertainties in climate change to predict the future of India's groundwater and address the water management problems. In this context, ensemble models on trends of temperature \& rainfall; spatio-temporal distribution of isotopes $\left({ }^{2} \mathrm{H},{ }^{3} \mathrm{H},{ }^{14} \mathrm{C},{ }^{18} \mathrm{O}\right)$ in rain water and groundwater; ${ }^{14} \mathrm{C}$-Ages of groundwater \& sediments; Lake deposits stratigraphy and vegetation pollen analysis in India have been reviewed to provide detailed insight into palaeo-climate, groundwater provenance, recharge and pollution characteristics, to predict groundwater challenge, which can help in devising appropriate water management and adaptation strategies.

\section{Materials and methods}

Extensive investigations were carried out for over four decades in the Northern and Western parts of India using artificially injected ${ }^{3} \mathrm{H}$ and natural abundances of radioactive $\left({ }^{3} \mathrm{H}\right.$, $\left.{ }^{14} \mathrm{C}\right)$, and stable $\left({ }^{2} \mathrm{H},{ }^{18} \mathrm{O}\right)$ isotopes in water cycle components, to assess groundwater recharge situation in major river basins (Datta et al., 1973; Datta and Goel, 1977; Goel et al., 1977; Borole et al., 1979; Datta et al., 1980, 1994, 1996, 1996a, 1997, 1999, 2001; Datta 2005, 2008, 2009). The spatial and temporal variations of ${ }^{18} \mathrm{O} /{ }^{16} \mathrm{O}$ and ${ }^{2} \mathrm{H} /{ }^{1} \mathrm{H}$ ratios in rain water, groundwater and river water were modelled to have insight into groundwater provenance, recharge characteristics, flow pathways of intermixing, contamination processes and pollutants dynamics, SW-GW interactions, and potential under river flood plains. The ${ }^{2} \mathrm{H}$ and ${ }^{18} \mathrm{O}$ values are expressed as $\delta^{2} \mathrm{H}$ and $\delta^{18} \mathrm{O}$ in per mille (\%o) deviations from the Standard Mean Ocean Water. ${ }^{14} \mathrm{C}\left(\mathrm{T}_{1 / 2}=5730 \mathrm{y}\right)$ was used to estimate groundwater ages (residence time) after correcting for ${ }^{14} \mathrm{C}$ in carbonates and bicarbonates in water. The evidences from the sedimentology, stratigraphy, ${ }^{14} \mathrm{C}$-age and pollen analysis of the salt-lake deposits and hydrology have been integrated to assess the palaeoclimate changes (Singh et al., 1974; Goudie, 1977; Agarwal et al., 1980; Wasson et al., 1983; Enzel et al., 1999). Methods of sampling and isotopic and chemical analyses are described in the cited references.

\section{Results and discussion \\ Projections on climate and evidences on palaeoclimate}

The anticipated projections on temperature and rainfall (Fig. 1) by the Intergovernmental Panel on Climate Change (IPCC 1996, 2001, 2007) based on sixteen GCMs (discrete grid) and increasing population induced three emission scenarios (viz., Self-reliant, independent nation; Rapid economy growth and Balanced energy; Integrated, ecofriendly and rapid economy growth) indicate that the differences in temperature are likely to emerge only after 2030, and there is no clear evidence of significant change in rainfall. The observational records (1901-2010) and reconstructed pre-monsoon anomalies (1725-2000) using tree-ring (Tectona grandis, Pinus, Picea, Cedrus, Abies, etc.) chronology network (Pant, 2003) clearly suggest decreasing trend or insignificant change in temperature and rainfall in India (Fig. 2); and climate during past 250 yrs was not significantly different than present (Dash et al., 2007), possibly due to meso-scale influences in lower atmosphere.

The literature indicate that during major part of Pleistocene (2My-12000 yrs BP), and the Last Glacial Maximum (30000 yrs BP), inter-pluvial climate with weak summer monsoon existed in the northwestern India (Singh et al., 1974; Goudie, 1977; Wasson et al., 1983). Consistent ${ }^{14} \mathrm{C}$-ages 23,000-38,000 yrs BP in inter-graded fluvial, semi-lacustrine and aeolian deposits in western Rajasthan also suggest palaeoclimate of rainfall fluctuations and semi-arid conditions during the late Tertiary and the Quaternary period (Agarwal et al., 1980). The current warm Holocene epoch started around 18,000 yrs BP, with weakening of Indian monsoon, and fluctuations in temperature, rainfall, wind patterns and sea-level. The Sambhar, Didwana and Lunkaransar salt-lakes and Pushkar freshwater lake deposits sedimentology, stratigraphy, ${ }^{14} \mathrm{C}$-age and pollen analysis (Fig. 3), in conjunction 

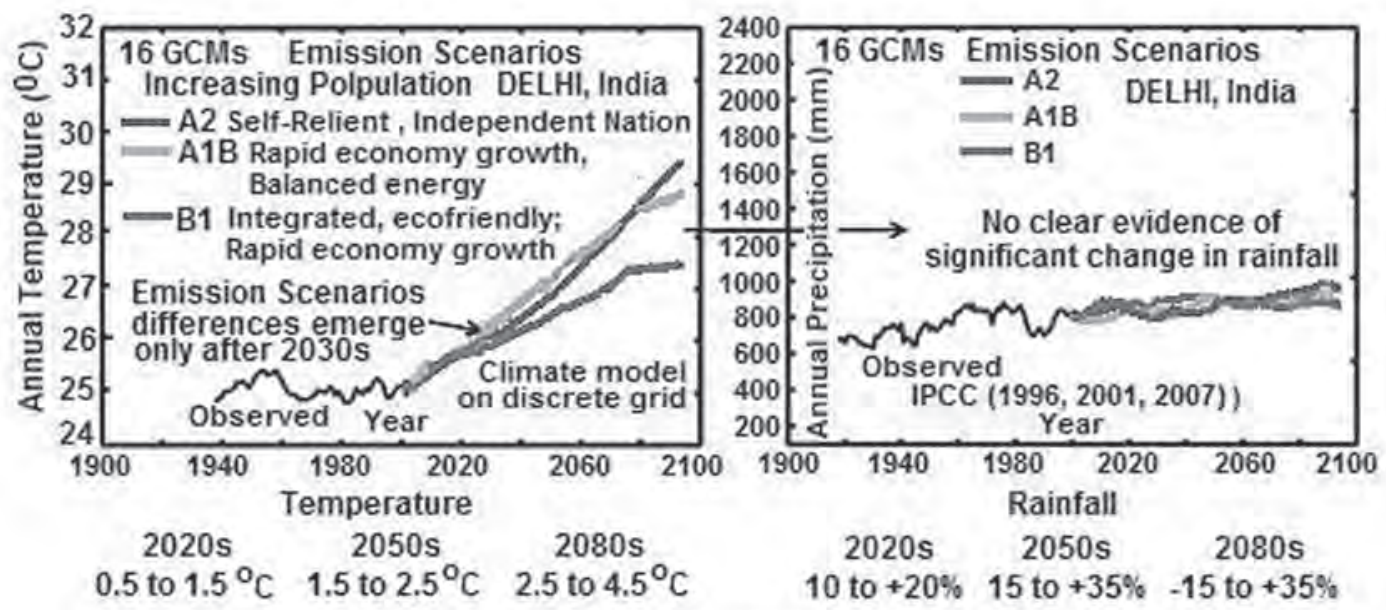

Indo-Gangetic Plains: Av. Rise $0.5-1{ }^{\circ} \mathrm{C}(2020-2029), 3.5-4.5^{\circ} \mathrm{C}(2090-2099)$

Fig. 1 - Anticipated projections on temperature and rainfall in India. (Source: International Panel on Climate Change - 1996, 2001, 2007)

Fig. 1 - Previsioni di temperatura e piovosità in India. (Fonte: International Panel on Climate Change - 1996, 2001, 2007)
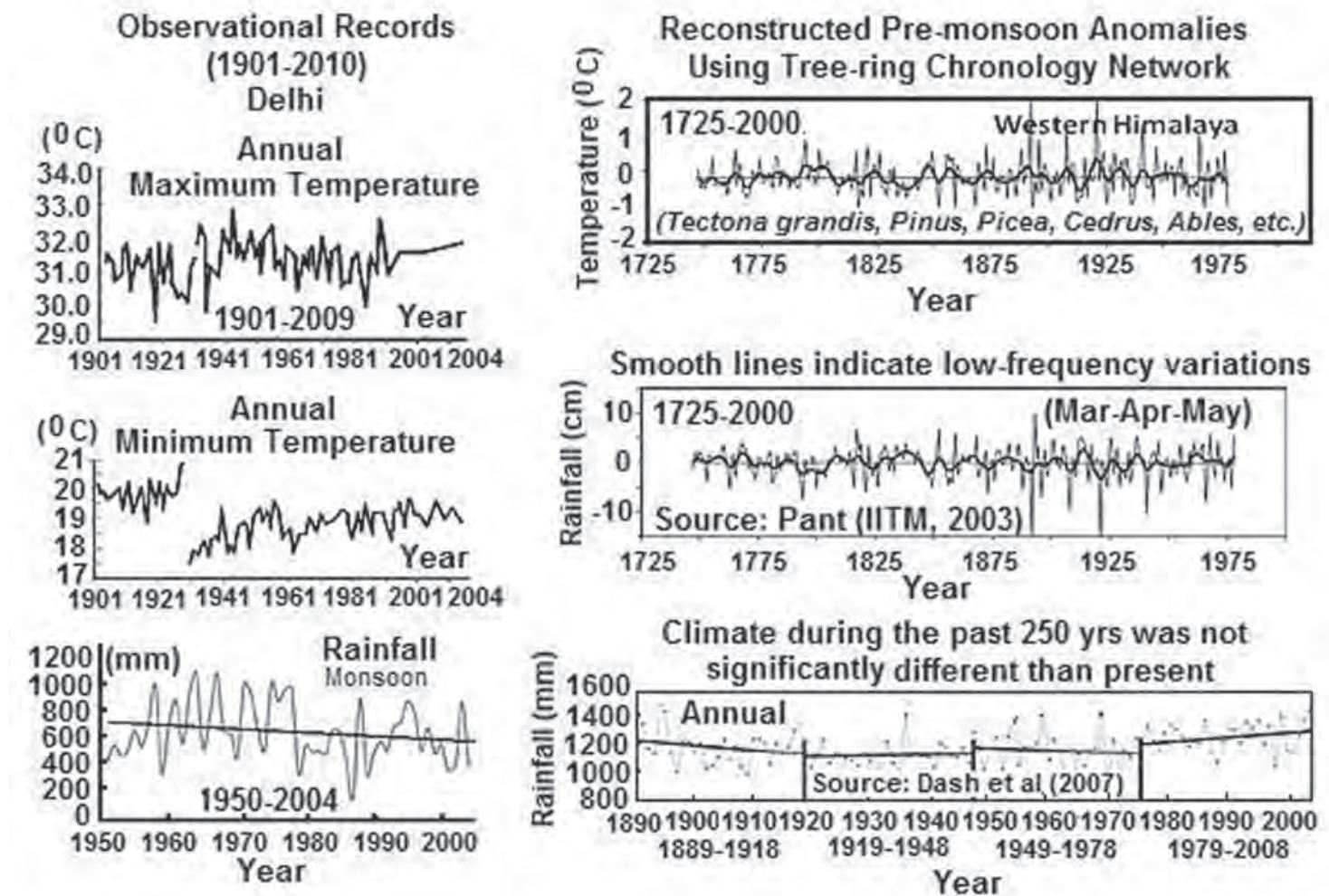

Fig. 2 - The observational records (1901-2010) and reconstructed pre-monsoon anomalies (1975-2000) using tree-ring chronology network (Pant, 2003) suggest decreasing trend or insignificant change in temperature and rainfall in India (Dash et al., 2007).

Fig. 2 - Le osservazioni registrate $(1901$ - 2010) e la ricostruzione delle anomalie pre-monsoniche (1975 - 2000) ottenute utilizzando la three-ring chronology network (Pant, 2003) hanno suggerito una tendenza decrescente (o comunque un cambiamento non significativo) per la variazione di temperatura e di piovosità in India (Dash et al. 2007). 
Five Phases of Paleo-Climate based on Lake Deposits Stratigraph, ${ }^{14} \mathrm{C}$-Age \& Pollen Analysis in NW-India

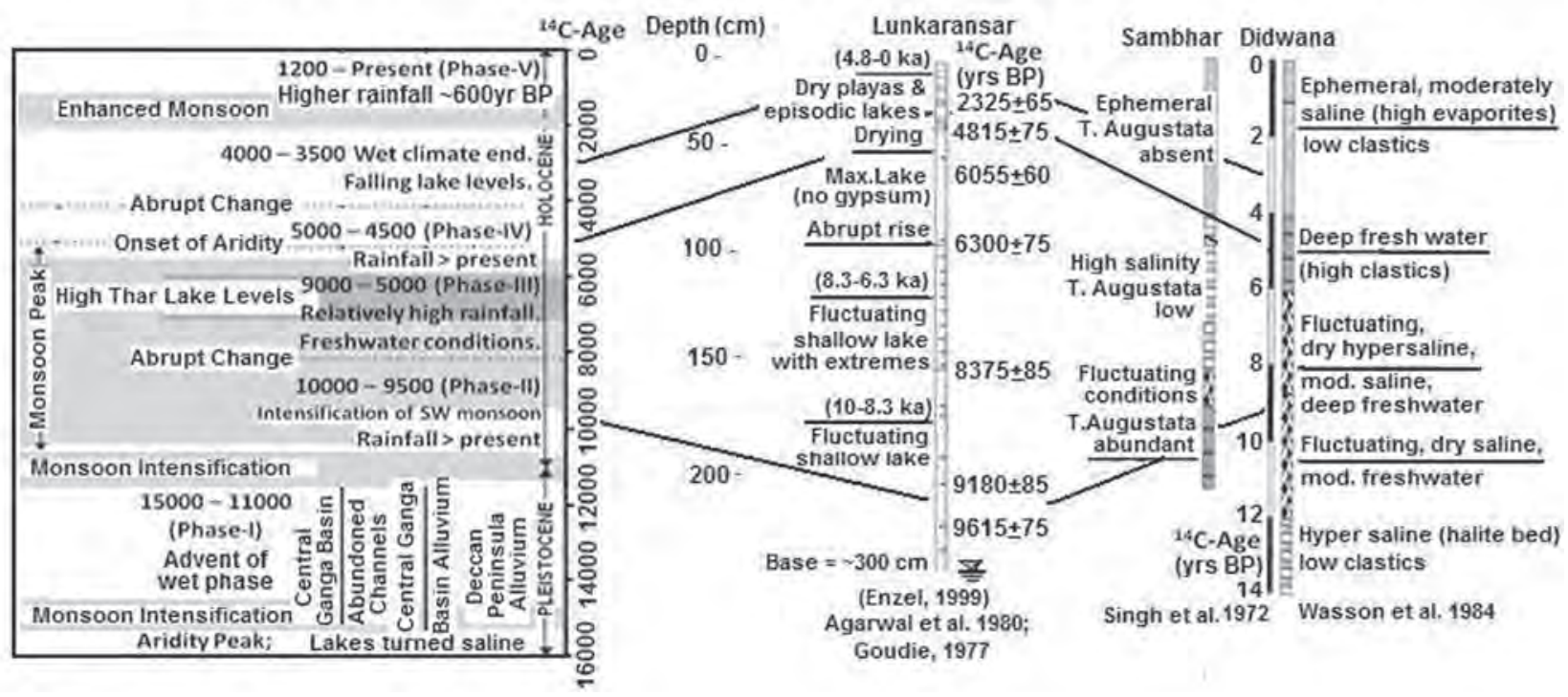

Fig. 3 - The Sedimentology, Stratigraphy, ${ }^{14} \mathrm{C}$-Age and Pollen Analysis of the Sambhar, Didwana and Lunkaransar salt lakes deposits in Rajasthan (India) indicating five phases of palaeoclimate.

Fig. 3 - Sedimentologia, stratigrafia, età del ${ }^{14} \mathrm{C}$, analisi dei pollini dei sedimenti nei laghi salati di Sambhar, Didwana e Lunkaransar nel Rajasthan, India che indicano le cinque fasi del paleoclima.

with archaeological evidences also indicate saline water conditions during 13000-20000 yrs BP suggesting aridity; and increase in rainfall and freshwater conditions in 6000-9000 yrs BP with intensification of vegetation cover inland (Singh et al., 1974). Very shallow level fluctuations in dry salt-lakes over decades to centuries in the early Holocene rose abruptly around $6300 \mathrm{yrs} \mathrm{BP}$ due to changes in the SW Indian monsoon rains (Enzel et al. 1999). In Budha Pushkar, Rajasthan, $14 \mathrm{C}$ dates $6000 \mathrm{yrs} \mathrm{BP}$ of the crust overlying sand dunes suggest termination of Late Pleistocene or early Holocene aridity by mid-Holocene with stabilization of sand dunes (Agarwal et al. 1980), which is in conformity with global trend of warmer/ wetter periods around 6400-3400 yrs BP and glaciers contraction around 5000-3000 yrs BP. During the late Holocene, widespread aridity followed this Phase immediately around 4000-4800 yrs BP, with falling lake water levels, salt-lakes drying, intense dune destabilization, and decline in taxa (indicative of summer/winter rainfall). No change in the climate is reported in the region in the last 1200 yrs BP to present, with good water availability, but, shifts in climatic belts were there in early Holocene and higher monsoon rainfall around 600 yrs BP (Singh et al., 1974).

\section{Relationship of palaeoclimate changes and groundwater recharge/contamination}

Studies (Singh et al., 1974; Goudie, 1977; and Wasson et al., 1983) in northwestern India suggest that during the LGM (30000-12000 yrs BP), variations in temperature and rainfall, originated or modified by inter-pluvial palaeoclimatic processes and weak summer monsoon, preserved high salinity surface water and groundwater in low permeability deeper aquifers and in some shallow aquifers through direct interaction with surface water such as lakes and rivers, and indirectly by rainfall recharge. In North-western and Gangetic Plains, highly depleted $\delta^{18} \mathrm{O}(-4.2 \% \circ$ to $-7.6 \%)$ in groundwater (Fig. 4) compared to present day weighted mean rainfall $(\sim 117 \mathrm{~cm})$ $\delta^{18} \mathrm{O}\left(-2\right.$ to $-6 \%$ ), with high ${ }^{3} \mathrm{H}(6-12 \mathrm{TU})$ and age of $<50$ yrs in the Gangetic Plains, and ${ }^{14} \mathrm{C}$ age of 2,000-22,000 BP, in Gujarat and Rajasthan, India (Borole, 1979; Sukhija, 1984, Rao, 2003, Datta, 2009, Garduño, 2009, Reddy et al., 2011) suggest occurrence of both modern recharge in shallow aquifers and at some places palaeowater which got recharged in the past during relatively humid climate. The ${ }^{14} \mathrm{C}$-dates (residence times), which are smoothed by diffusion and dispersion, suggest slow flushing rate of groundwater in the last Interglacial period with dry-arid climate compared to the present.

The analysis of the IAEA-GNIP data of India (Datta et al. 1991) shows rainfall mean $\delta^{18} \mathrm{O}(-2 \%$ o to $-6 \%$ ), and longterm mean rainfall and temperature together account for about $80-95 \%$ of the long-term average variability of Delhi rainfall monthly mean $\delta^{18} \mathrm{O}$ from $-15.3 \%$ to $+8.0 \%$ and $\delta^{2} \mathrm{H}$ from $-120 \%$ to $+55.0 \%$, and depleted $\delta^{18} \mathrm{O}$ is generally associated with heavy rainfall. The slope $\leq 8$ in local meteoric water lines in different parts of India (Fig. 5) indicate minor to significant evaporation of rainfall before groundwater recharge. However, the groundwater $\delta^{18} \mathrm{O}$ exhibit reasonable correspondence with rainfall $\delta^{18} \mathrm{O}$; and the groundwater $\delta^{18} \mathrm{O}$ data (URL: http://www.prl.res.in/\%7Ewebprl/web/announce/ ind-gw.pdf) of India indicate three broad groups (Fig. 6, 7): $<-4 \% \circ$ (North-western and Gangetic Plains), $-4 \%$ to $-2 \% 0$ (Southeast coast Plains) and $>-2 \%$ (Western Ghats and Deccan Plateau). The depth variation in groundwater ${ }^{14} \mathrm{C}$-age 


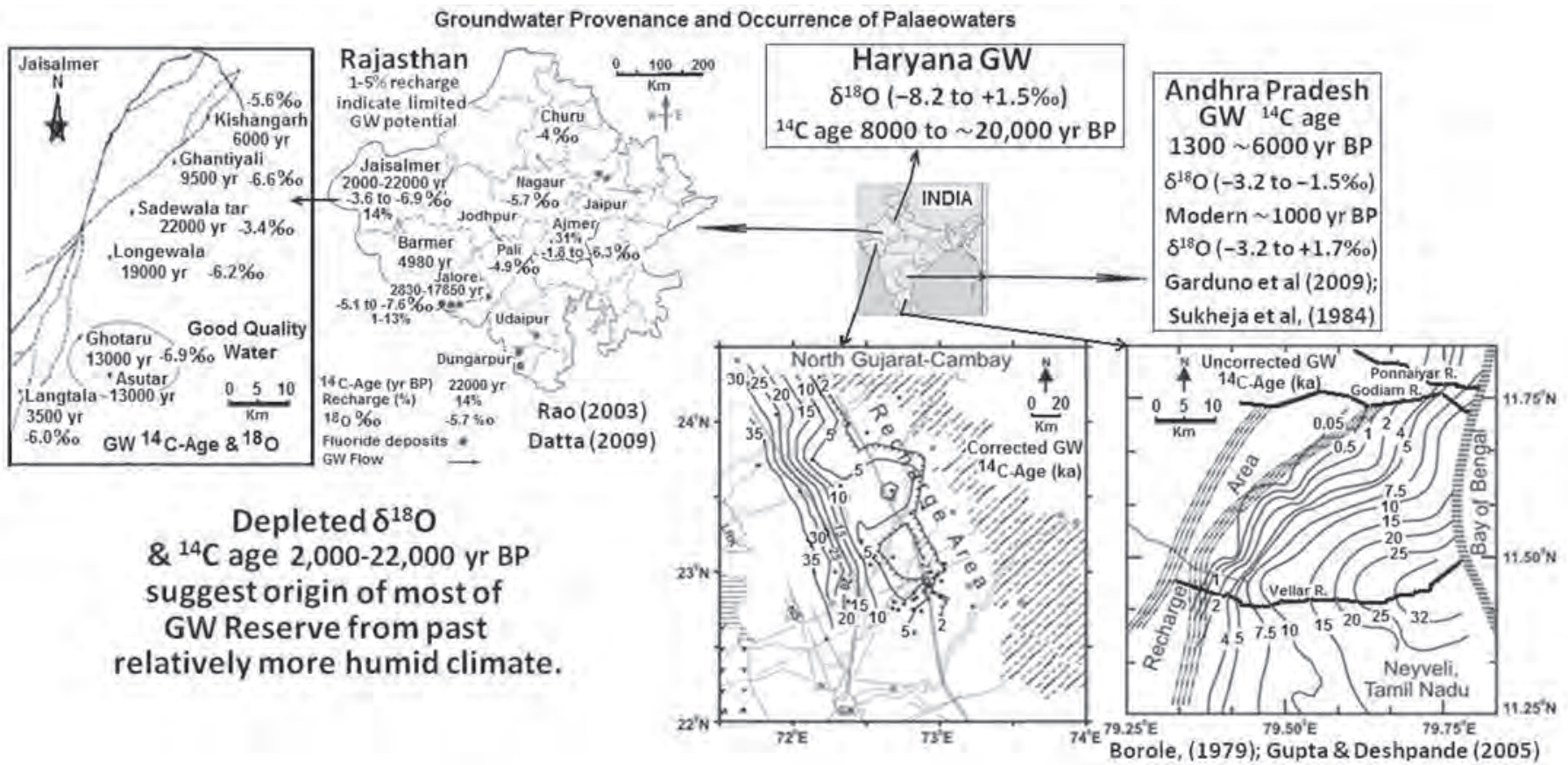

Fig. 4 - Groundwater provenance and occurence in North Western and Gangetic Plains, India. Highly depleted $\delta^{18} \mathrm{O}(-4,2 \%$ to $-7.6 \%)$ in groundwater compared to present day weighted main rainfall $\delta^{18} \mathrm{O}$, with ${ }^{3} \mathrm{H}$ age $<50 y \mathrm{r}$ and ${ }^{14} \mathrm{C}$-age $200022000 \mathrm{yr} \mathrm{BP}$ in Gujarat and Rajasthan, suggest occurrence of both modern recharge in shallow aquifers and at some places palaeowater which got recharged in the past during relatively bumid climate.

Fig. 4 - Origine e presenza delle acque sotterranee nel Nord Ovest e nella pianura del Gange, India. L'isotopo $\delta^{18} \mathrm{O}(-4.2 \%$ o to $-7.6 \%$ ) altamente impoverito nelle acque sotterranee comparato con gli attuali valori della media pesata giornaliera di $\delta^{18} \mathrm{O}$ nelle piogge, con età del ${ }^{3} \mathrm{H}<50$ anni ed età ${ }^{14} \mathrm{C}$ degli ultimi $2,000-22,000$ anni, in Gujarat e Rajasthan. Questi dati suggeriscono la presenza di entrambi i tipi di ricarica, quella recente negli acquiferi superficiali e in alcuni luoghi quella delle paloeacque che sono state ricaricate nel passato nel corso del clima umido.

\section{Local Meteoric Water Lines In India}

\section{Slope is governed by processes; Intercept by water Source/Origin/Nature}

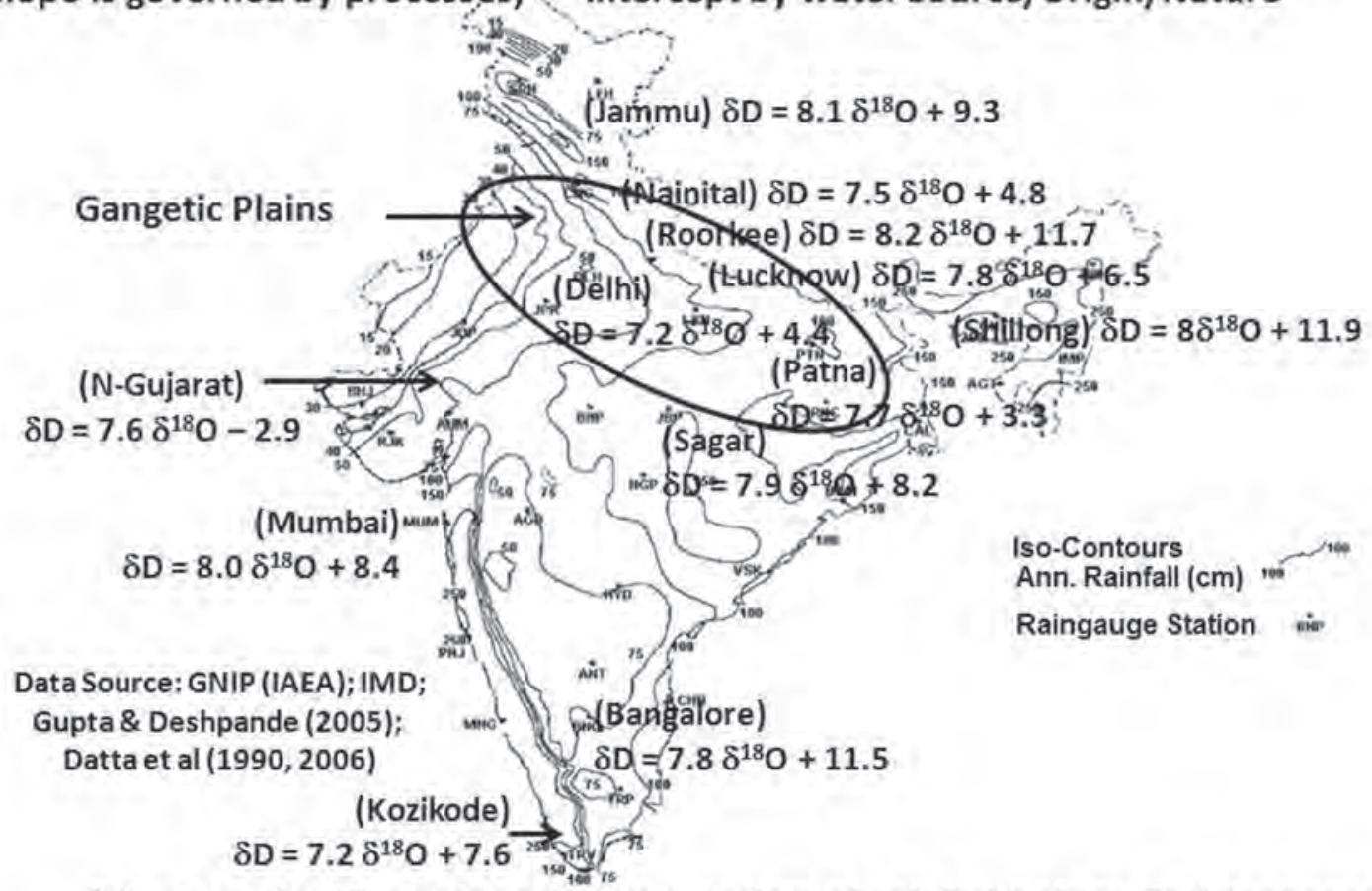

Minor to significant kinetic evaporation of rainfall before GW recharge.

Fig. 5 - The Local Meteoric Water lines in India indicates significant evaporation of rainfall before groundwater recharge.

Fig. 5 - Le linee delle acque di precipitazione locale in India evidenziano un significativo tasso di evaporazione prima che le acque possano ricaricare quelle sotterranee. 


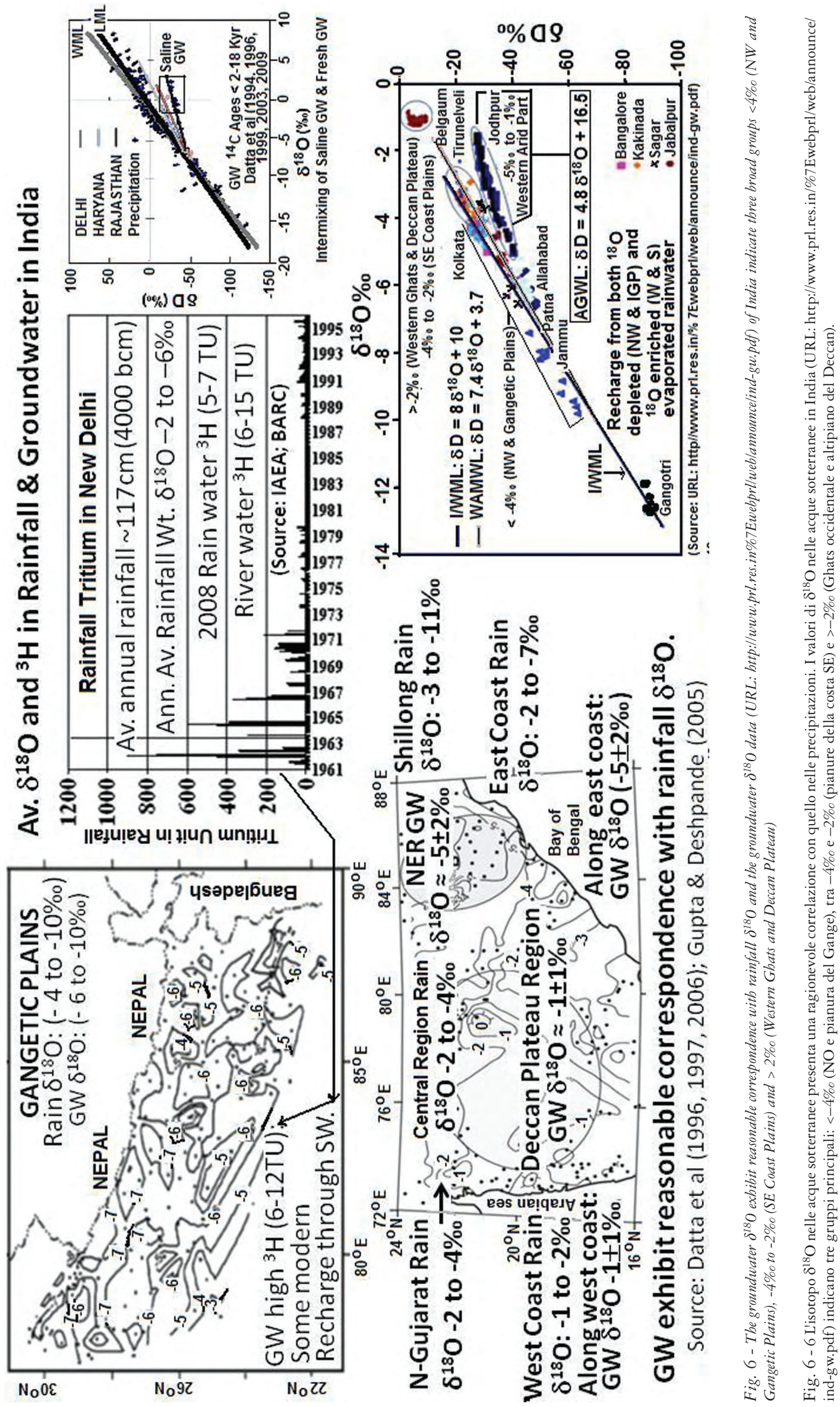




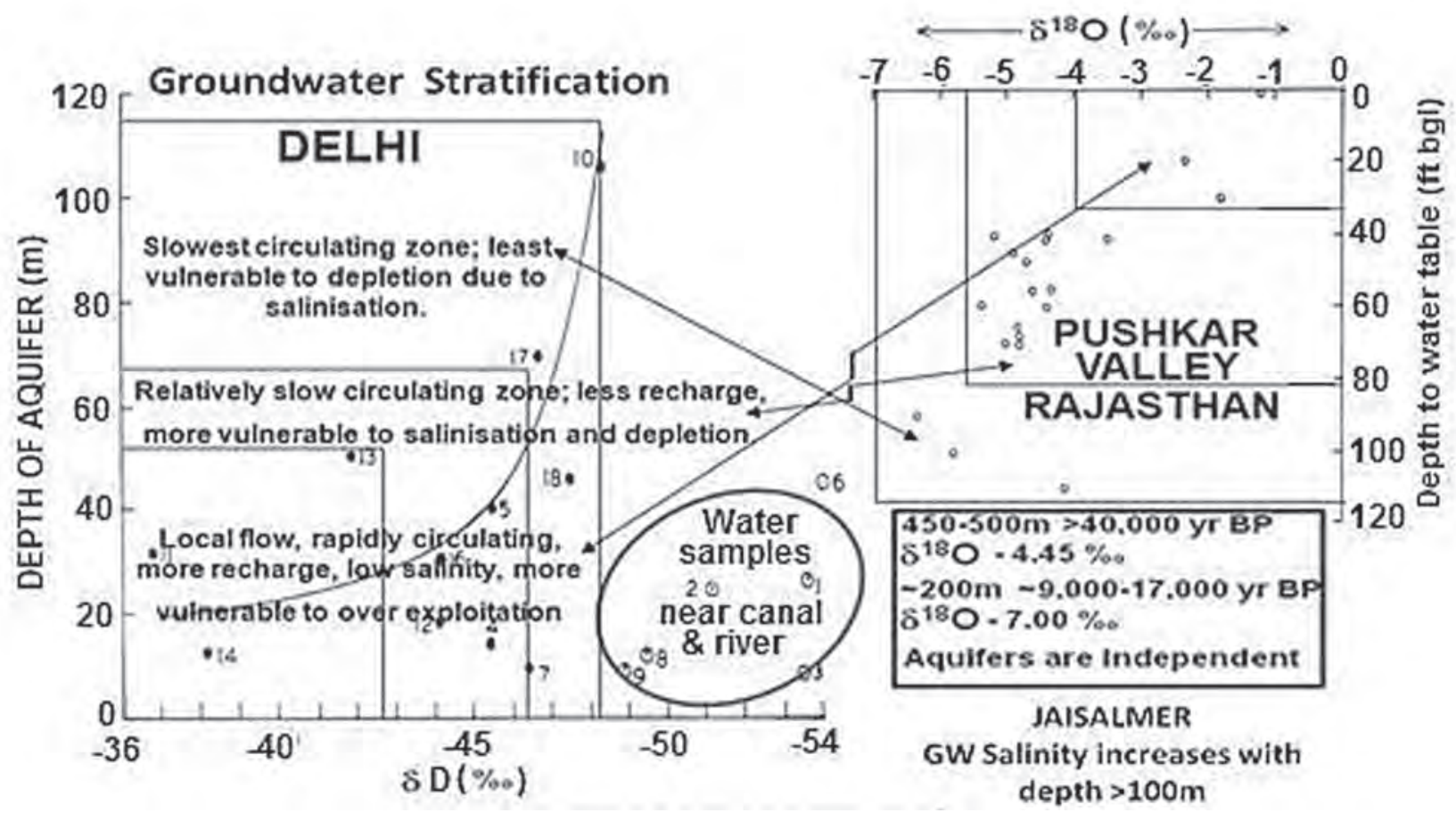

Fig. 7 - The depth variation in groundwater ${ }^{14} \mathrm{C}$-age and $\delta^{18} \mathrm{O}$ suggest inhomogeneity and vertical stratification, and the depht and thickness of the stratified zones vary from area to area.

Fig. 7 - La variazione in profondità di ${ }^{14} \mathrm{C}$ e $\delta^{18} \mathrm{O}$ suggerisce una inomogeneità La profondità e lo spessore delle zone stratificate variano da area ad area.

and $\delta^{18} \mathrm{O}$ (Fig. 7) suggests vertical stratification (Datta et al., 1994; Datta, 2009; Reddy et al., 2011), and the depth and thickness of the stratified zones vary from area to area.

\section{Incommensurate recharge with withdrawal}

The average groundwater recharge has been estimated to be $<8 \%$ to $20 \%$ of the annual rainfall ( $660-1000 \mathrm{~mm} / \mathrm{yr})$ in the semi-arid States of Delhi (Datta, 2001); Western UP (Datta et al., 1973); Haryana (Goel et al., 1977); Punjab (Datta and Goel, 1977); and Gujarat (Datta et al., 1980; Gupta and Deshpande, 2005) (Fig. 8); and 1-14\% of annual rainfall ( 140-300 $\mathrm{mm} / \mathrm{yr}$ ) in Rajasthan (Sharma and Gupta, 1987). Increasing urbanisation reduced the area directly exposed to rainfall intake for groundwater recharge decreasing the groundwater potential. Although, it is not certain how individual water catchment area correspond with changes in temperature and rainfall, yet, IPCC (2007) projected climate induced anticipated increase in temperature and snow-melt runoff may increase recharge in the Indo-Gangetic Plains; and anticipated rise in sea level may threaten coastal aquifer by saline water intrusion. However, decline in Himalaya glaciers retreat since 1970 and higher variability and declining trends in monsoon months' rainfall may decrease recharge.

Groundwater sustainability also faced a major challenge during the past 2-3 decades due to land use changed induced unethical and indiscriminate withdrawal of groundwater as compared to very small annual recharge, leading to water table decline by 2-8 $\mathrm{m}$ to $20-60 \mathrm{~m}$ in different parts of highly urbanized Delhi, Punjab, Uttar Pradesh, Haryana, Gujarat, Rajasthan (Datta, 2005, 2009; Chatterji and Purohit, 2009) and some parts in south India (Fig. 9). In highly urbanized Delhi area, the fluctuations in temperature and rainfall influenced the groundwater levels (Datta et al., 2004) (Fig. 10). In 1977, due to high rainfall and less temperature anomaly groundwater table remained within 6-8 m bgl. But, in 1983 , less rainfall caused decline in water table to $10-14 \mathrm{~m}$ bgl. During 1993 -1996, normal rainfall and less temperature anomaly kept the water table stable. But, during 1979 \&1989, 1999 \& 2002 , very low rainfall and high temperature anomaly caused considerable decline in water table.

Fresh water availability has been also constrained by both past and on-going pollution of groundwater. More than half of the Indian wells groundwaters are moderately to highly polluted (CPCB 2007). While, groundwater of about $>10$ 95\% wells in northern, western and southern states is polluted with fluoride; in about $5-30 \%$ wells of eastern states, groundwater is polluted with As; about $25-100 \%$ of wells in eastern, northeastern, and some southern and northern states are polluted with high Fe. A large number of wells in northern and western states Punjab, Haryana, Delhi, Uttar Pradesh, Rajasthan and Gujarat is polluted with moderate to high salinity, fluoride $\left(<1-46.0 \mathrm{mg} \mathrm{l}^{-1}\right)$ and nitrate $(<20-1600$ $\left.\mathrm{mg} \mathrm{l}^{-1}\right), \mathrm{Zn}, \mathrm{Cu}, \mathrm{Pb}, \mathrm{Ni}, \mathrm{Cd}$, exceeding the WHO prescribed maximum permissible limits in drinking water, contributed 
Groundwater Recharge (\%) from Rainfall in North-West India
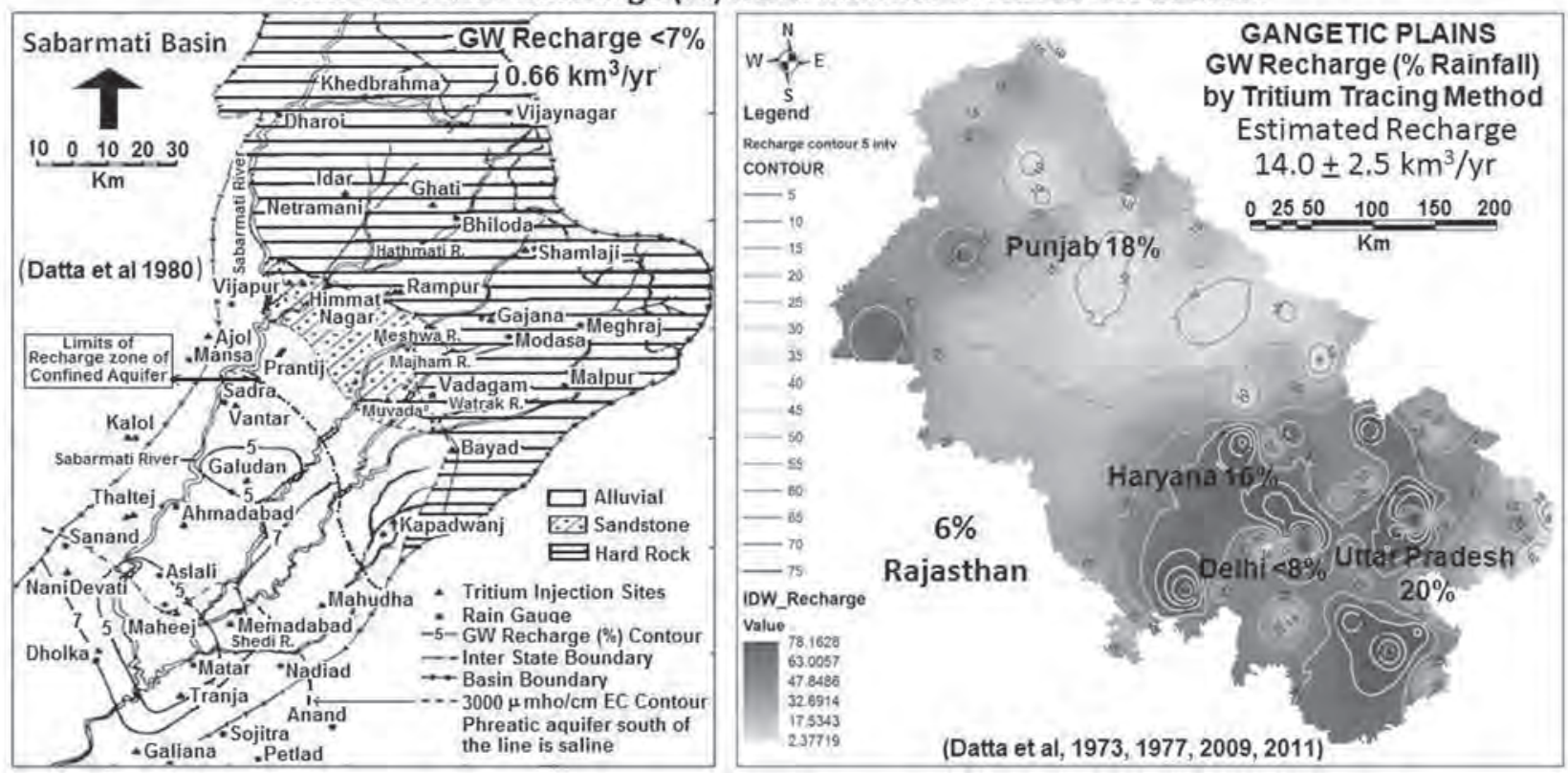

Fig. 8 - The estimated average groundwater recharge (\% annual rainfall) in the State of Delhi (Datta, 2000, 2001); Western Uttar Pradesh (Datta et al., 1973); Haryana (Goel et al., 1977); Punjab (Datta and Goel, 1977); Gujarat (Datta et al., 1980; Gupta and Deshpande, 2005) and Rajasthan (Sharma and Gupta, 1985).

Fig. 8 - Stima della ricarica media (in \% della piovosità annuale) negli Stati di Delhi (Datta 2000, 2001), Western UP (Datta et al., 1973), Haryana (Goel et al., 1977), Punjab (Datta and Goel, 1977), Gujarat (Datta et al., 1979, 1980; Gupta and Deshpande, 2005) e Rajasthan (Sharma and Gupta, 1987).

\section{Present Av. GW Recharge from Rain in India: $11.5 \pm 3.6 \%$}

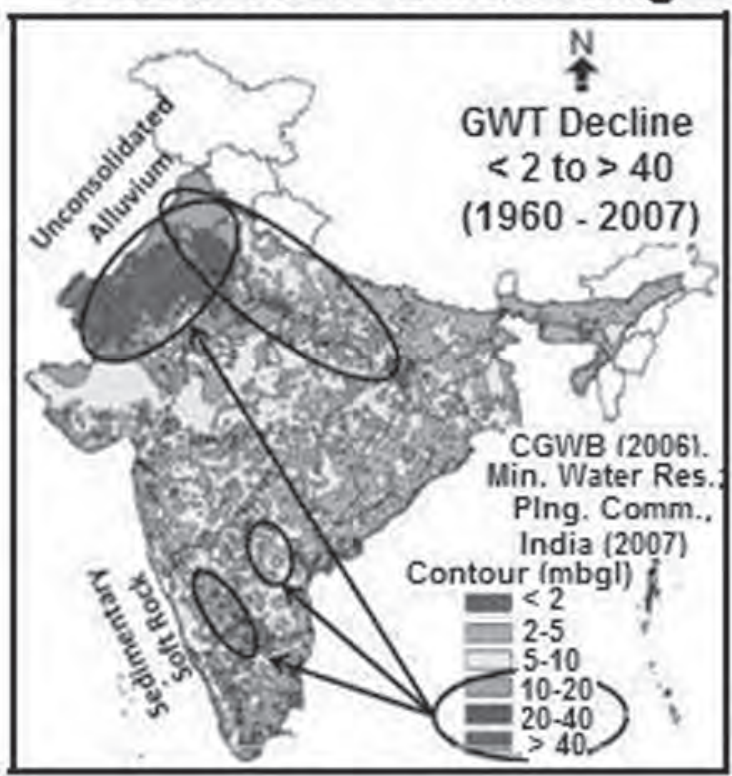

GW development: $100-300 \%$ (Delhi)

$125 \%$ (Punjab), $109 \%$ (Haryana)

$125 \%$ (Rajasthan), $70-100 \%$ (UP)

$85 \%$ (Tamil Nadu), $76 \%$ (Gujarat)

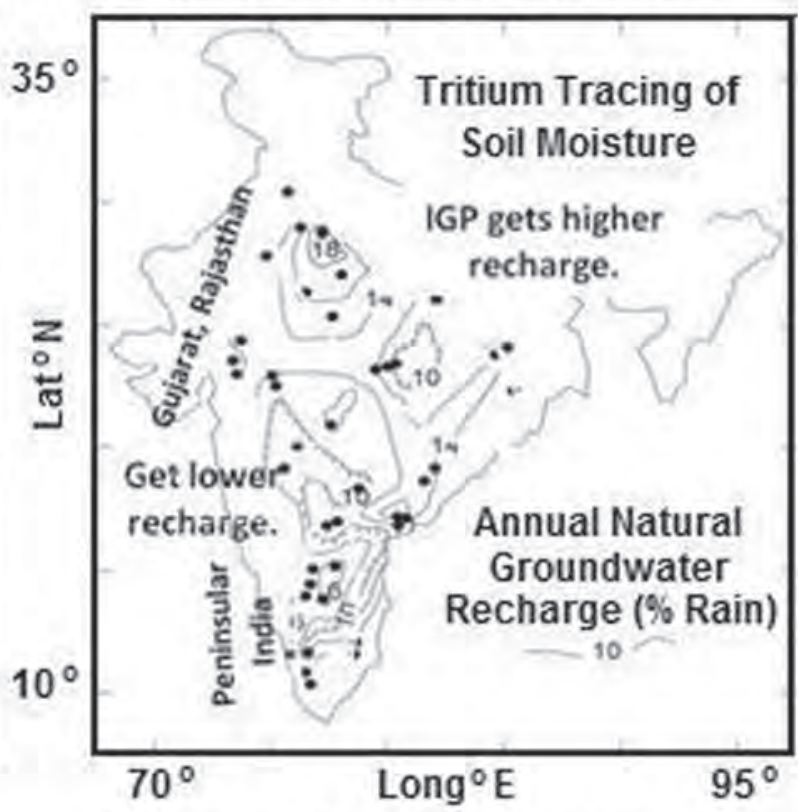

More urbanization has reduced the area directly exposed to rainfall intake for GW recharge, decreasing the GW potential.

Fig. 9 - Withdrawal of groundwater as compared to very small recharge, leading to water table decline by 2-8 $m$ to 20-60 $m$ in different parts of highly urbanized Delhi, Punjab, Uttar Pradesh, Haryana, Gujarat and Rajasthan (Datta et al., 1973,1977, 1980, 2009; Gupta and Deshpande, 2005).

Fig. 9 - Il prelievo di acque sotterranee a fronte di ricariche annuali molto ridotte comporta un abbassamento del livello delle acque sotterranee da 2-8 m a 20-60 m in diverse zone ad alta urbanizzazione di Delhi, Punjab, Uttar Pradesh, Haryana, Gujarat, Rajasthan (Datta et al., 1973, 1977, 1980, 2009; Gupta and Deshpande, 2005). 


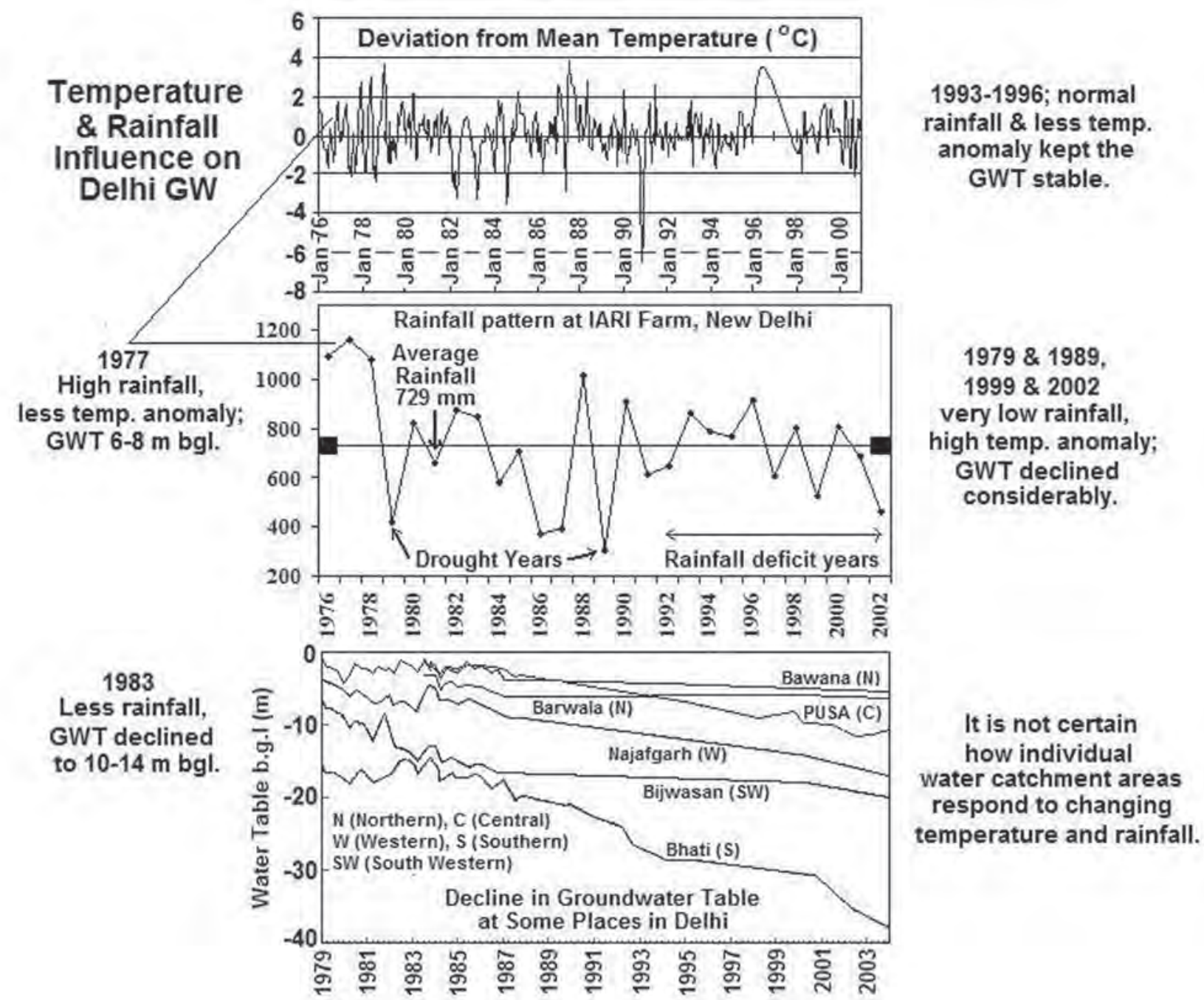

Fig. 10 - The groundwater levels indicate the influence of temperature and rainfall.

Fig. 10 - I livelli delle acque sotterranee indicano l'influenza di temperatura e piovosità.

from both non-point and point sources (Datta et al., 1996a, 1997, 1999, 2001). In the absence of known major geological source of fluoride, nitrate, $\mathrm{Zn}$, and $\mathrm{Cu}$, the increasing pollutants levels with increase in $\delta^{18} \mathrm{O}$ indicate that pollution has been mainly ascribed to slow infiltration of pollutants chemicals present in agricultural and urban run-off, and anthropogenic wastes on land, in river and unlined drains, governed by degrees of evaporation/recharge and adsorption/dispersion processes in the soil (Datta et al., 1996a, 1997, 1999). From the straight line relationship of groundwater $\delta^{18} \mathrm{O}$ and contaminants species concentration, flow-pathways of groundwater intermixing were identified in the Delhi area (Datta et al., 1996a, 1997, 1999). The iso-contours contaminants (Fig. 11) clearly indicate the flow-pathways of polluted groundwater plumes, and over-exploitation induced intermixing of such polluted groundwater with freshwater or river water, which increase the lateral extent of polluted groundwater, thereby decreasing uncontaminated groundwater availability.
For recharge to be responsive to climate induced groundwater pollution, a conceptual predictive model (Soni et al., 2009) has been developed on the premise of layer-by-layer transport of percolating water in the unsaturated soil, in which, rain ' $R$ ' falling in ' $T$ ' packets on soil (with thickness ' $H$ " from land surface to water table, specific moisture ' $m$ ', soil particulate matter 's') will have recharge quantity ' $h=(1-m-s) H / N$ ', and at each time step, $\mathrm{T}=\mathrm{R} / \mathrm{h}=\mathrm{NR} /(1-\mathrm{m}-\mathrm{s}) \mathrm{H}$. The water after entering the soil and complete mixing in layer ' $n$ ' leaves this sub-layer and enters layer ' $\mathrm{n}+1$ ' with volume $\mathrm{v}[\mathrm{n}+1]$, and the net Recharge to a layer $=($ Input to the layer $)+($ Mixing in free volume) - (Output from the layer) - (retention inside the volume). In this model, taking advantage of natural decontamination of infiltrating water along diffuse circulation and recharge paths, it is possible to decontaminate a geologically closed unconfined aquifer basin in 6-10 yrs, by planned withdrawal of polluted water from the aquifer and allowing rainfall to recharge, by cordoning of the recharge zone from 

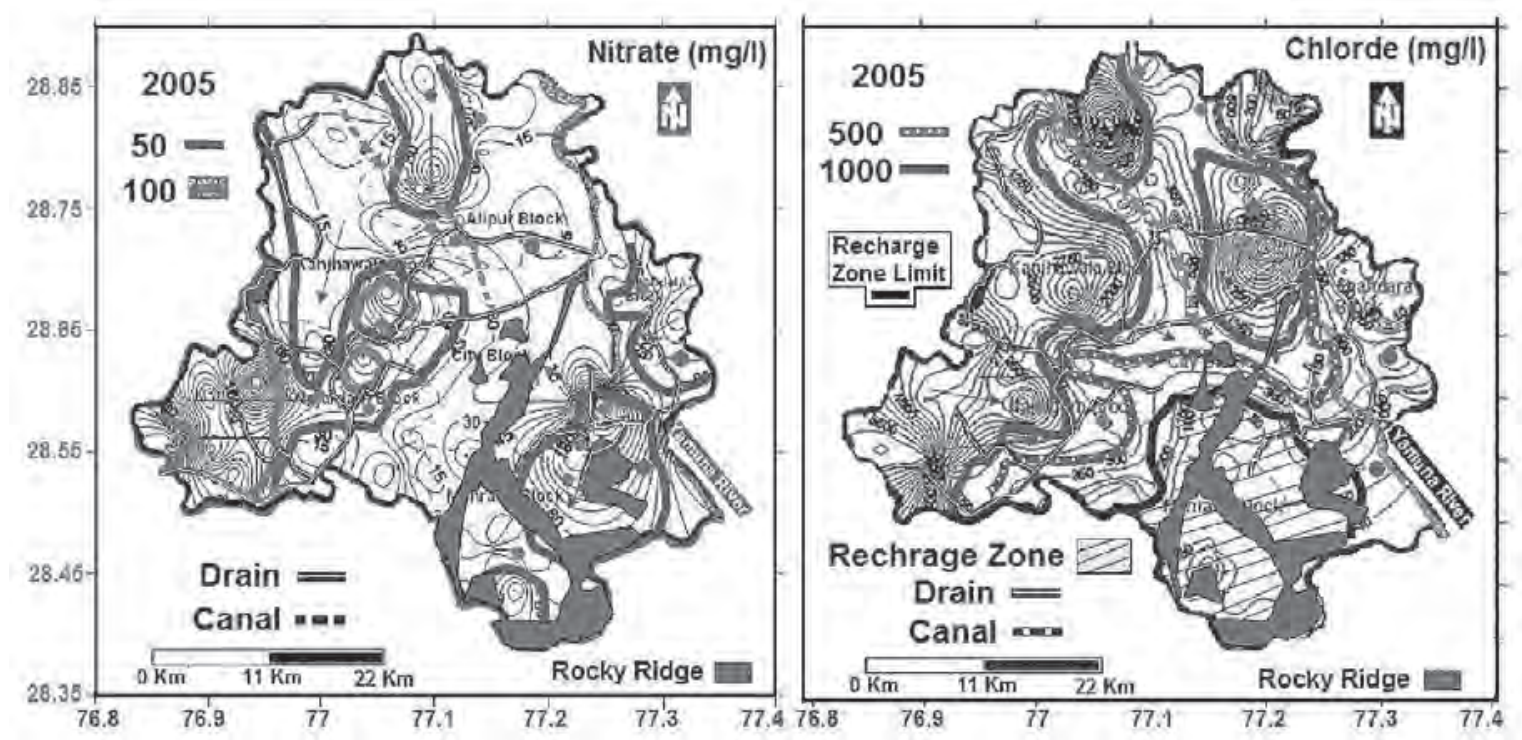

Fig. 11 - The iso-contours of contaminants in groundwater indicating pollution plumes in Delhi area.

Fig. 11 - Le iso-concentrazioni di contaminanti nelle acque sotterranee evidenziano i pennacchi di contaminazione nell'area di Delhi.

influence of human activities. Another mixing model (Datta and Kumar, 2011), taking advantage of good interconnection of the Yamuna river water $\left(\delta^{18} \mathrm{O}-9.7 \% 0\right)$ and the adjacent groundwater $\left(\delta^{18} \mathrm{O}-5.6 \%\right.$ to $\left.-9.6 \% 0\right)$ in shallow wells, indicates $2-96 \%$ contribution of river water to groundwater under the flood plains at different stretches. To make recharge to be responsive to climate, large volume of runoff expected from increasing snow melt by the anticipated climate change can be conserved under the floodplains and let surface water infiltrate in the hyporheic zone (Datta and Kumar, 2011) and avoid river bed clogging.

\section{Concluding remarks}

The ensemble of models based on the observational records of temperature and rainfall, and isotopic studies on paleoclimate indicate no clear evidence on climate change in India during the last 1000 yrs BP. The temperature and rainfall show declining trend or not significant change during last 50 years; and also suggest that in the early quaternary, NorthWest India was well watered. Deep aquifers groundwater got preserved during the LGM (30000-12000 yrs BP) pluvial climate, and shallow aquifers got recharged by interaction with lakes and rivers. Groundwater occurrence and quality differ from region to region and within the parts of a region. In most of the places, low recharge percentage indicates limited groundwater storing or renewal potential of the reservoir over the past decades after decades. Not denying the fact that climate induced warming is evident in many parts of the globe, however, there is no evidence of direct impact of climate on Indian groundwater regimes, and it is harder to predict.

Going by the IPCC projections, in India, the anticipated increase in mean annual temperature from global warming may decrease winter rainfall, increase summer rainfall and surface runoff, reduce groundwater recharge where surface runoff de- clines, and may cause more accumulation of wastes. For climate resilient groundwater management, it may be useful to create an integrated system of adequate water supply, based on spatial and temporal variation in different timescales of groundwater recharge, from high-resolution palaeo-data. In any area, groundwater flow often contains a transient component governed by natural groundwater recharge rates, and hydraulic properties of the aquifer system. Since, the groundwater withdrawals generally comprise both recent and past recharge components, and the present to past recharge ratio is large in humid areas and small in arid areas, transient and steady-state conditions prevail at low recharge rates and at high recharge rates, respectively. Hence, for groundwater management, if transient component is ignored in areas with low/high recharge and high/low discharge, groundwater safeyield is likely to be over-estimated or under-estimated, leading to groundwater depletion and unsustainable development in the long run.

To reduce water consumption and wasteful utilisation, the practical measures could be strict regulatory enforcement to price groundwater extraction, stop wastes discharge into the hydrological system, and conserving flood water in the aquifers under river floodplains. For groundwater recharge to be a major response to climate resilient groundwater management, it is desirable to monitor variability in recharge \& pollution dynamics; groundwater flow-pathways of intermixing, effluent/influent seepage, and revise and reconsider all such assessments time to time, in relation to the changes in land/ water use; and expand geographical coverage of paleowaters and vertical stratification from high-resolution data on paleoclimate records, and evolve integrated groundwater management strategy considering different timescales of recharge. It is also desirable to identify pollution sources and strategies for containment of pollution spreading from known sources; 
develop vulnerability maps of groundwater pollutants levels; delineate potential groundwater recharge \& protection zones. It is further necessary to assess past successes \& failures and adjust policies according to local condition; conduct studies on competition among water users (private and public); intersectoral (irrigated agriculture and urban water supplies); examine people's adaptive strategies, etc., when water scarcity is faced; and promote recharge in hotspot areas, to reduce GHG emissions from pumping. To effectively implement the measures, it is necessary to identify the factors aggressive to depletion and degradation of groundwater, by thorough volumetric estimates of groundwater under natural and stressed conditions, its long-term socio-economic needs/demands in consultation with the users, and the policy implications, guided by ethical considerations.

\section{REFERENCES}

Agarwal D P, Datta P S, Husain Zahid, Krishanmurthy R V, Mishra V N, Rajaguru S N, Thomas P K (1980) Paleoclimate, stratigraphy and prehistory in north and west Rajasthan. Proc Ind Acd Sc. (Earth Planet Sci) 89(1): 51-66.

Anchukaitis K J, Buckley B M, Cook E R, Cook B I, D'Arrigo R D and Ammann C M (2010) Influence of volcanic eruptions on the climate of the Asian monsoon region. Geophys Res Let 37, L22703, doi:10.1029/2010GL044843, 2010.

Borole D V, Gupta S K, Krishanswami S, Datta P S, Desai B I (1979) Uranium isotopic investigations and radiocarbon measurement of river-groundwater systems, Sabarmati Basin, Gujarat, India. Isotope Hydrology IAEA Vienna IAEA-SM-228/11 1: 118-201.

CPCB (Central Pollution Control Board, Ministry of Environment and Forests) (2007) Status of Groundwater Quality in India. Groundwater Quality Series: GWQS/ 09/2006-2007 February 2007

Cai Y, An Z, Cheng H, Edwards R L, Kelly M J, Liu W, Wang X, Shen C C (2006) High-resolution absolute-dated Indian Monsoon record between 53 and 36 ka from Xiaobailong Cave, southwestern China. Geology 34: 621-624.

Chatterjee, Rana \& Purohit, Raja Ram (2009) Estimation of replenishable groundwater resources of India and their status of utilization. Current Science, 25 June, 2009. vol. 96(12): 1581-1591.

Chiang, John C.H. (2009) The Tropics in Paleoclimate. Annu Rev Earth Planet Sci 37:263-97

Dash S K, Jenamani R K, Kalsi S R, Panda S K (2007) Some evidence of climate change in twentieth-century India. Climatic Change 85: 299-321

Datta P S (2005). Groundwater ethics for its sustainability, Current Sci, 10 September 89(5): 1-6.

Datta P S (2009) Keynote Talk, Isotopic Evidences of Climate Influence on Groundwater Provenance and Desertification in Rajasthan Region and Adaptation Strategies, Proc. Int. Conf. Nurturing Arid Zones for People and the Environment Issues and Agenda for the 21st Century, CAZRI, Jodhpur, Nov 24-28.
Datta P S, Bhattacharya S K, Mookerjee P, Tyagi S K (1994) Study of groundwater occurence and mixing in Pushkar (Ajmer) Valley, Rajasthan with ${ }^{18} \mathrm{O}$ and hydrochemical data. J. Geol. Soc. India. 43: 446-456

Datta P S, Bhattacharya S K, Tyagi S K (1996) ${ }^{18}$ O studies on recharge of phreatic aquifers and groundwater flow paths of mixing in Delhi area. J Hydrol 176: 25-36.

Datta P S, Deb D L, Tyagi S K (1996a) Stable isotope $\left({ }^{18} \mathrm{O}\right)$ investigations on the processes controlling fluoride contamination of groundwater. J Contaminant Hydrol 24(1): 85-96.

Datta P S, Deb D L, Tyagi S K (1997) Assessment of groundwater contamination from fertilizers in Delhi area based on ${ }^{18} \mathrm{O}, \mathrm{NO}_{3}{ }^{-}$and $\mathrm{K}^{+}$composition. J Contaminant Hydrol 27(3-4): 249-262.

Datta P S, Desai B I, Gupta S K (1980) Hydrological investigations in Sabarmati basin-I. Groundwater recharge estimation using tritium tagging method. Proc. Ind. Natn. Sci. Acad., Phys. Sci., 46(1): 8498.

Datta P S, Goel P S (1977) Groundwater recharge in Punjab state (India) using tritium tracer. Nordic Hydrol 8: 225-236.

Datta P S, Goel P S, Rama, Sangal S P (1973) Groundwater recharge in western Utter Pradesh. Proc Ind Acd Sci 78(Sec. A): 1-12.

Datta P S, Kumar S (2011) Significance of ${ }^{18} \mathrm{O}$ and hydrochemical composition to characterize water dynamics in hyporheic zone of Yamuna river flood plains in Delhi Area. Proc. 3rd International Multi-disciplinary Conference on Hydrology and Ecology: Ecosystems, Groundwater and Surface water - Pressures and Options, Vienna, Austria May 2-5, 2011.

Datta P S, Manjaiah K M, Tyagi S K (1999) ${ }^{18} \mathrm{O}$ isotopic characterisation of non-point source contributed heavy metal ( $\mathrm{Zn}$ and $\mathrm{Cu}$ ) contamination of groundwater. Ext. Abs. Proc. International Symposium on Isotope Techniques in Water Resources Development and Management, May 10-14, 1999, Vienna, IAEA-SM-361/35, 77-79.

Datta P S, Rohilla S K, Tyagi S K (2001) Integrated approach for water resources management in Delhi region: Problems and perspectives. In: Regional Management of Water Resources, Proc. Maastricht Assembly Symposium, July, 2001, IAHS Publ. No. 268, 1-8.

Datta P S, Tyagi S K and Chandrasekharan H (1991) Factors controlling stable isotopes in precipitation in New Delhi, India, J. Hydrol 128: 223-236.

Datta P S, Tyagi S K, Mookerjee P, Bhattacharya S K, Gupta Navindu, Bhatnagar P D (1998) Groundwater $\mathrm{NO}_{3}$ and $\mathrm{F}$ contamination processes in Pushkar Valley, Rajasthan as reflected from ${ }^{18} \mathrm{O}$ isotopic signature and ${ }^{3} \mathrm{H}$ recharge studies. Environ Monitor Assess, $1-11$.

Enzel Y, Ely L L, Mishra S, Ramesh R, Amit R, Lazar B, Rajaguru S N, Baker V R, Sandler A (1999) High-Resolution Holocene Environmental Changes in the Thar Desert, Northwestern India. Science 2 April 1999 284(5411): 125-128. doi: 10.1126/science.284.5411.125

Garduño Héctor, Foster Stephen, Raj Pradeep, Steenbergen Frank van (2009) Addressing Groundwater Depletion Through Communitybased Management Actions in the Weathered Granitic Basement Aquifer of Drought-prone Andhra Pradesh - India. Sustainable Groundwater Management - Lessons from Practice, Case Profile Collection Number 19, April 2009, The World Bank Global Water Partnership Associate Programme

Goel P S, Datta P S, and Tanwar B S (1977) Measurement of vertical recharge to groundwater in Haryana state (India) using tritium tracer. Nordic Hydrol. 8: 211-224.

Goudie A (1977) Environmental Change, Clarendon Press, Oxford, U.K. 
Gupta S K, Deshpande R D (2005) Groundwater isotopic investigations in India: What has been learned? Current Science, 10 September 2005. Vol. 89(5): 825-835.

Pant G B (2003) Long-term climate variability and chage over monsoon Asia. J Ind Geophys Union 7(3):125-134

IPCC $2^{\text {nd }}, 3^{\text {rd }}$ and $4^{\text {th }}$ Assessment Reports $(1996,2001,2007)$ Publications. http://www.ipcc.ch/publications_and_data/publications_ and_data_reports.shtml\#.UT2A6ta7K $7 \mathrm{w}$

Reddy D V, Nagabhushanam P, Rao M R, Mitra D S, Tripati B M, Sinha S K , Bhadu B (2011) Radiocarbon Evidence of Paleo-recharge (pre-Saraswati period) of Potential Deep Aquifer in Thar Desert. J Geol Soc India, 77: 239-242. doi: 0016-7622/2011-773-239/\$1.00 (C) GEOL. SOC. INDIA

Rao S M (2003) Use of isotopes in search of Lost River. Journal of Radioanalytical and Nuclear Chemistry, Vol. 257(1): 5-9
Sharma P and Gupta S K (1987) Isotopic investigation of soil water movement: a case study in the Thar Desert, western Rajasthan. Hydrol Sci, J des Sciences Hydrologiques 32(4) 12/1987.

Singh G, Joshi R D, Chopra S K, and Singh A B (1974) Late Quaternary History of Vegetation and Climate of the Rajasthan Desert, India. doi: 10.1098/rstb.1974.0006. Philos Trans R Soc London 267(889): 467-501.

Soni V, Mehrotra R, Datta P S, and Chander S, (2009) 'A Process for Organic Water'. Current Sci 25 April 2009 96(8): 1100-1103.

Sukhija B S, Reddy D V, Nagabhushanam P, Bhattacharya S K, Jani R A, Kumar Devender (1984) Characterisation of recharge processes and groundwater flow mechanisms in weathered-fractured granites of Hyderabad (India) using isotopes. Hydrogeol J 14: 663-674, doi: 10.1007/s10040-005-0461-6

Wasson J R, Rajaguru S N, Misra V N, Agarwal D P, Dhir R P (1983) Geomorphology, late Quaternary stratigraphy and paleoclimatology of the Thar dunefield. Z Geomorph N F 45: 117-151. 